\title{
HUBUNGAN ANTARA DERAJAT OBSTRUKSI SALURAN NAFAS SERANGAN AKUT ASMA DENGAN JUMLAH SEL-SEL INFLAMASI DARAH TEPI
}

\section{(THE ASSOCIATION BETWEEN ACUTE ATTACK OF ASTHMA SEVERITY AND THE NUMBER INFLAMATION OF PERIPHERAL BLOOD CELLS)}

\author{
HMS. Chandra Kusuma *, Kusworini Handono Kalim **, Masdar Muid *** \\ *Bagian IImu Kesehatan Anak Fakultas Kedokteran Unibraw/ RSU Dr. Saiful Anwar Malang \\ " Bagian Patologi Klinik Fakultas Kedokteran Unibraw/ RSU Dr. Saiful Anwar Malang \\ *** Bagian IImu Kesehatan Anak, Divisi Neurologi Fakultas Kedokteran Unibraw/ RSU Dr. Saiful Anwar Malang
}

\begin{abstract}
There now exists compelling evidence of a role for cell-mediated immunity in the pathogenesis of asthma, but little information is available as to what extent this process participates in the disease severity. The hypothesized of this reseach that the severity of acute asthma exacerbation in children is associated with the activation of T-lymphocytes whose products regulate, at least in part, the mobilization and recruitment of eosinophyls and thereby disease severity. The aims of this research, therefore, were to compare the peripheral blood T-lymphocytes from acute asthmatic and no asthmatic normal control children matched for age and sex, and to attempt to correlate the percentages of T-lymphocytes in the asthmatic with the numbers of peripheral blood eosinophyls and with disease severity. Fifty one children with acute asthma exacerbation were compared with thirty one no asthmatic, normal children matched for age and sex. Peripheral blood CD4+ and CD8+ T-lymphocytes was measured using immuno histochemical staining. Peripheral blood eosinophils were measured using an automated laser cytometer. Asthma exacerbation severity was assessed by a symptom score and spirometri. The absolute numbers of eosinophils and CD4+T-lymphocytes of the asthmatic were elevated as compared to the non-asthmatic normal control, whereas the numbers of CD8+ T-lymphocyte decreased significantly. There was a significant correlation between elevated numbers of eosinophyls and CD4+ T-lymphocytes, and decreased numbers of CD8+ Tlymphocyte with the acute asthma exacerbation severity. Conclusions. The CD4+ T-lymphocytes, CD8+ T-lymphocyte and eosinophyls play a crucial role in the acute asthma exacerbation severity.
\end{abstract}

Key words: FEV1, Th2 CD4, Th1 CD8+, Ratio Th2 CD4+Th1 CD8+, eosinophil

\section{PENDAHULUAN}

Asma adalah penyakit kompleks dengan gambaran klinis yang sangat bervariasi baik anak maupun dewasa. Asma sebagai suatu penyakit mempunyai karakteristik seperti adanya obstruksi saluran nafas, hiperresponsivitas bronkus dan inflamasi saluran nafas.

Definisi asma yang tepat masih menjadi perdebatan tapi secara praktis pada umumnya dinyatakan sebagai obstruksi menyeluruh saluran nafas yang bersifat reversibel dengan reversibilitas FEV 1 (Forced Expiratory Volume in 1 Second) lebih besar dari $12 \%$.

Bukti yang menunjukkan adanya proses inflamasi dalam saluran nafas penderita asma adalah hasil pada otopsi penderita asma yang meninggal karena serangan asma, ditemukan adanya infiltrasi sel-sel neutrofil, eosinofil, sel mast yang mengalami degranulasi, penebalan membrane sub basalis, hilangnya integritas sel epitel, hipertropi dan hiperplasi, sel goblet serta penutupan lumen bronkus oleh mokus.

Studi bronkoskopi pada penderita asma ringan menunjukkan bahwa sel-sel eosinofil, limfosit $\mathrm{T}$, sel mast dan epitel terlibat langsung dalam patogenesa terjadinya asma ringan sampai berat. Tetapi tindakan bronkoskopi pada asma serangan

Jurnal Kedokteran Brawijaya, Vol. XX, No.3, Desember 2004. Korespondensi: HMS. Chandra Kusuma; Lab. IKA FK Unibraw; Jl. Veteran Malang-65145; telp (0341) 580991, 567192 fax (0341)564755 berat sangat sulit dilakukan (1)

Beberapa studi menunjukkan bahwa pada asma terjadi gangguan keseimbangan antara sel Th1 dan Th2 dengan pergeseran kearah Th2 $(2,3,4)$.

Oleh karena tindakan bronkoskopi sulit dilakukan pada asma serangan berat apalagi pada anak-anak maka perlu dilakukan upaya lain yang lebih mudah untuk membuktikan adanya hubungan antara sel-sel inflamasi dengan derajat obstruksi saluran nafas yang terlibat dalam patogenesa asma yaitu dengan melakukan pemeriksaan dari darah tepi.

Tujuan penelitian ini untuk mencari hubungan antara derajat serangan akut asma dengan jumlah sel inflamasi yang ada didalam darah tepi.

\section{METODE}

Yang diikutkan dalam penelitian ini adalah semua penderita asma yang mengalami serangan akut dan masuk rumah sakit mulai 1 Januari 2002 s/d Desember 2003 di ruang anak RSUD Dr. Saiful Anwar, RS Lavalette dan RSI Aisyah di Malang. Sebagai kontrol adalah 31 anak sehat, yang tidak pernah menderita /didiagnosis sebagai asma yang datang ke poliklinik anak RSUD Dr. Saiful Anwar yang datang untuk immunisasi. Umur sesuai dengan umur penderita asma yang masuk dalam penelitian.

Diagnosis asma dibuat atas dasar adanya serangan mengi (sesak dengan suara Iwheezing) berulang dan pemeriksaan 
spirometri menunjukkan reversibilitas $\geq 15 \%$ atau FEV $1 \leq 90 \%$. Derajat serangan asma ditentukan oleh nilai FEV 1 :

- Ringan : FEV $1 \geq 80 \%$

- Sedang: FEV $1 \geq 60 \% \leq 80 \%$

- Berat : FEV $1 \leq 60 \%$

Semua orang tua penderita yang ikut dalam penelitian menandatangani surat persetujuan (Informed Consent) dan penelitian sudah disetujui komite etik rumah sakit.

Penelitian ini merupakan studi cross-sectional. Pada hari pertama masuk rumah sakit segera di ukur faal paru, pengambilan darah tepi melalui vena untuk menghitung jumlah sel eosinofil, Th $\mathrm{CD}_{4}{ }^{+}$dan $\mathrm{Tc}_{\mathrm{C}} \mathrm{CD}_{8}{ }^{+}$. Pengukuran faal paru dengan menggunakan Spirometer Auto Spiror discom 21.

Nilai terbaik dari tiga kali pengukuran digunakan dalam penelitian yang tergambar sebagai persentasi nilai prediksi dan ditentukan segera setelah penderita masuk rumah sakit. Riversibilitas diukur setelah penderita mendapatkan $1-3$ kali inhalasi solbutamol.

Penghitungan jumlah sel eosinofil dilakukan dengan mesin hitung Sysmex XT 2000i Auto Reader. Penghitungan sel Th $\mathrm{CD}_{4}{ }^{+}$ dan $\mathrm{Tc}_{\mathrm{C}} \mathrm{CD}_{8}{ }^{+}$dengan menggunakan reaksi imuno histokimia dako L SAB 2 system. Analisis data statistik menggunakan program SPSS versi 10.0

\section{HASIL PENELITIAN}

Telah berhasil dikumpulkan 51 kasus asma dan 31 orang anak sehat sebagai kontrol. Distribusi jenis kelamin anak asma adalah 40 laki-laki dan 11 orang perempuan dengan rasio 3.6. Kontrol anak sehat 15 laki-laki dan 16 perempuan.
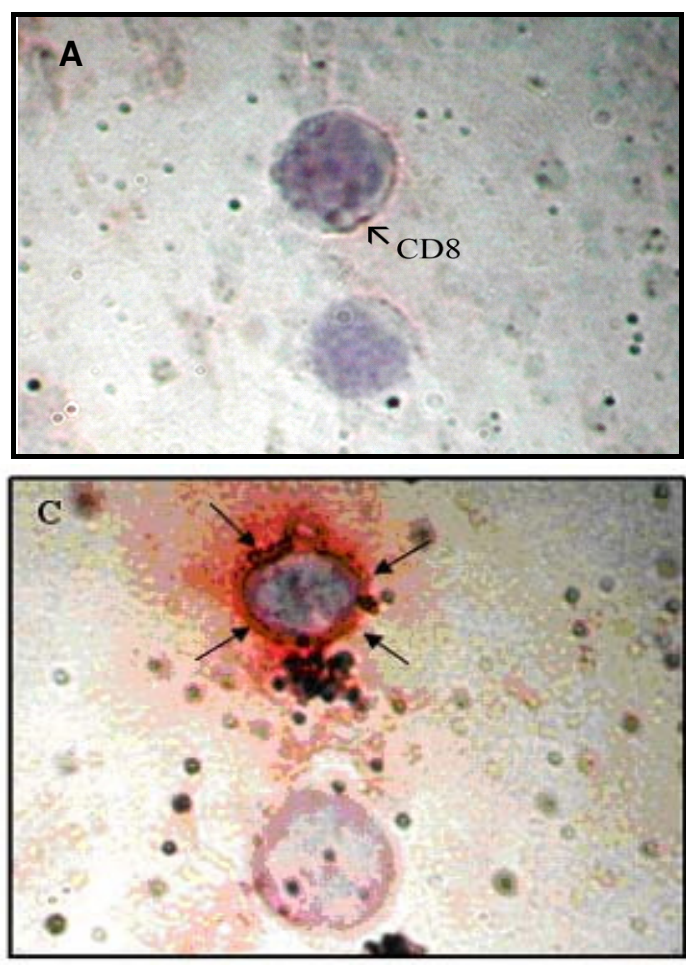

\section{B}
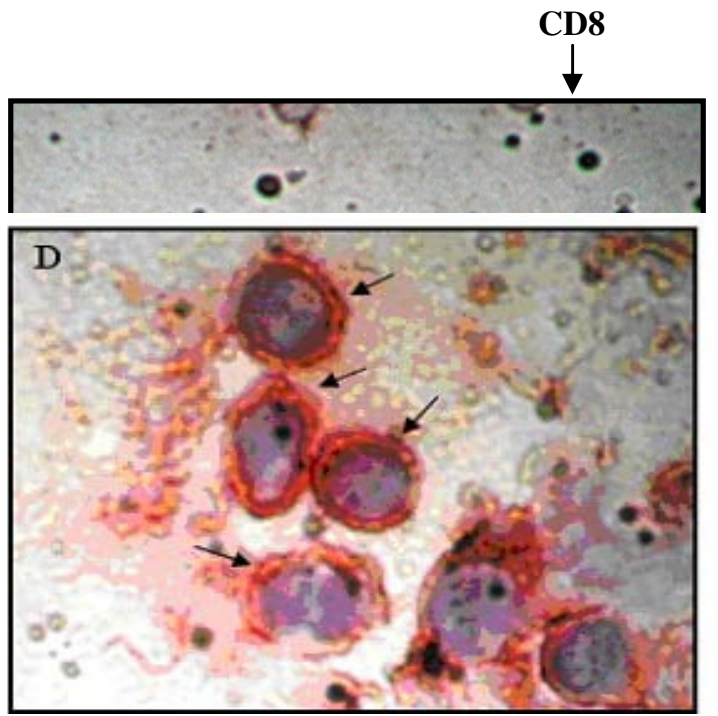

Gambar 1. Sel Tc CD8+ (A dan B) dan sel Th CD4+ (C dan D) (perbesaran 1000x) Tanda panah pada sel $T$ menurut DAKO EnVision Doublestain System (Imunohistokimia)

Tabel 1. Hasil Analisis Diskriptif

\begin{tabular}{lrrrr}
\hline \multirow{2}{*}{ VARIABEL } & \multicolumn{2}{c}{ Asma(+) bronkiolitis RSV } & \multicolumn{2}{c}{ Anak sehat } \\
\cline { 2 - 5 } Uerata & \multicolumn{1}{c}{ SD } & Rerata & SD \\
\hline Umur (tahun) & 8,1 & 1,7 & 7,9 & 1,2 \\
FEV1 (\%) & 61,32 & 8,19 & 97,71 & 6,24 \\
Eosinofil & 520,83 & 467,08 & 186,14 & 106,28 \\
ThCD4+ & 74,88 & 12,24 & 40,00 & 13,15 \\
TcCD8+ & 25,12 & 12,24 & 60,00 & 13,15 \\
ThCD4+ / TcCD8+ & 4,0900 & 2,5866 & 0,7357 & 0,3699 \\
\hline
\end{tabular}


Dari Tabel 1 terlihat bahwa pada penderita asma jumlah sel eosinofil dan jumlah sel $\mathrm{Th} \mathrm{CD}_{4}{ }^{+}$mempunyai nilai rerata yang lebih besar tetapi jumlah sel $\mathrm{Tc}^{\mathrm{C}} \mathrm{CD}_{8}{ }^{+}$lebih kecil dibandingkan kontrol anak sehat.
Dari Gambar 2 dan terlihat bahwa penurunan nilai $\mathrm{FEV}_{1}$ mempunyai korelasi yang bermakna dengan kenaikan jumlah eosinofil, Th $\mathrm{CD}_{4}{ }^{+}$dan penurunan jumlah sel $\mathrm{Tc}_{\mathrm{CD}}{ }^{+}$.

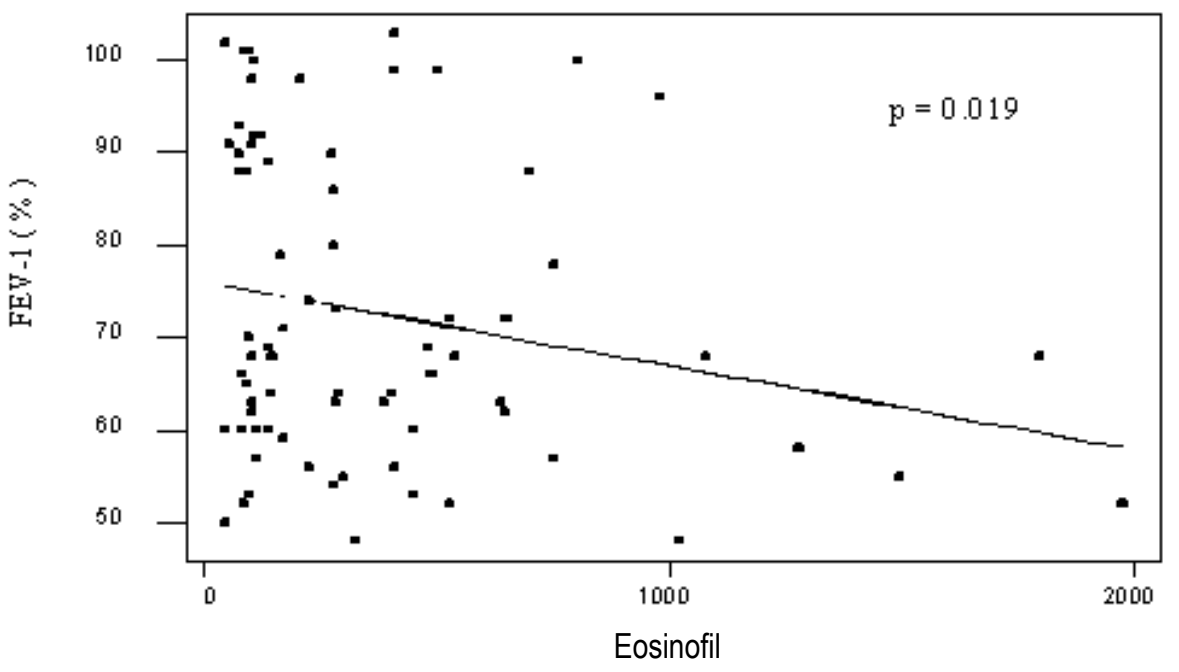

Gambar 2. Hubungan antara derajat asma dengan Eosinofil (Regression Plot)

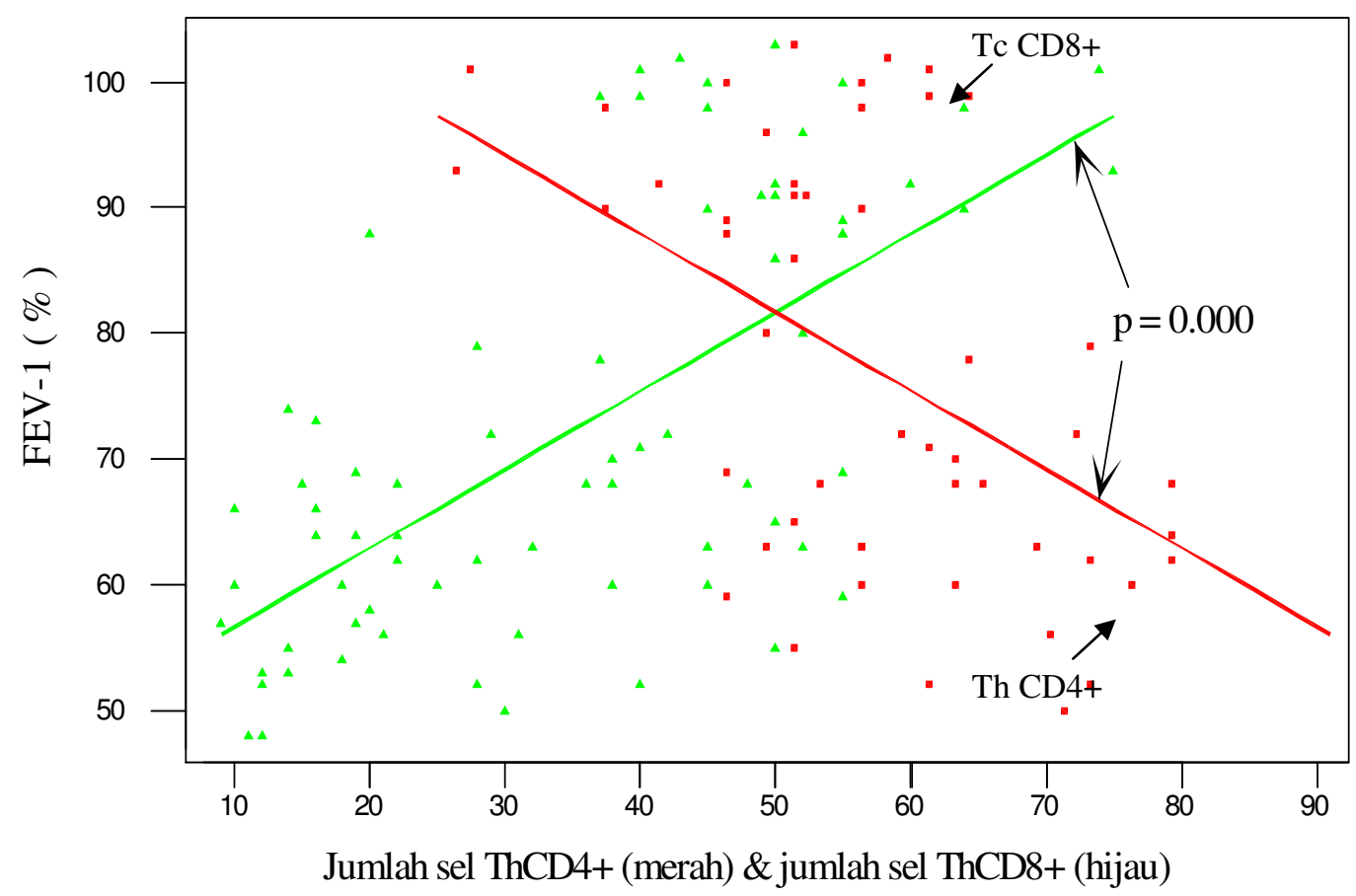

Gambar 3. Hubungan antara derajat asma dengan jumlah sel ThCD4+ dan TcCD8+ (Regression Plot)

Pada Gambar 2 terlihat bahwa semakin besar jumlah eosinofil darah tepi makin rendah nilai $\mathrm{FEV}_{1}$ dengan $p=0.019$. Pada Gambar 3 terlihat bahwa makin besar jumlah sel Th $\mathrm{CD}_{4}{ }^{+}$ dan makin rendah jumlah sel $\mathrm{Tc}_{\mathrm{C}} \mathrm{CD}_{8}{ }^{+}$di darah tepi makin rendah nilai $F E V_{1}$ dengan $p=0.000$.
Dengan membandingkan derajat obstruksi serangan asma yang diukur dengan $\mathrm{FEV}_{1}$ tampak bahwa makin besar rasio $\mathrm{Th}$ $\mathrm{CD}_{4}{ }^{+} / \mathrm{Tc} \mathrm{CD}_{8}{ }^{+}$makin besar derajat obstruksi yang terjadi (makin rendah nilai $\mathrm{FEV}_{1}$ ) dengan $\mathrm{p}=0.000$. 


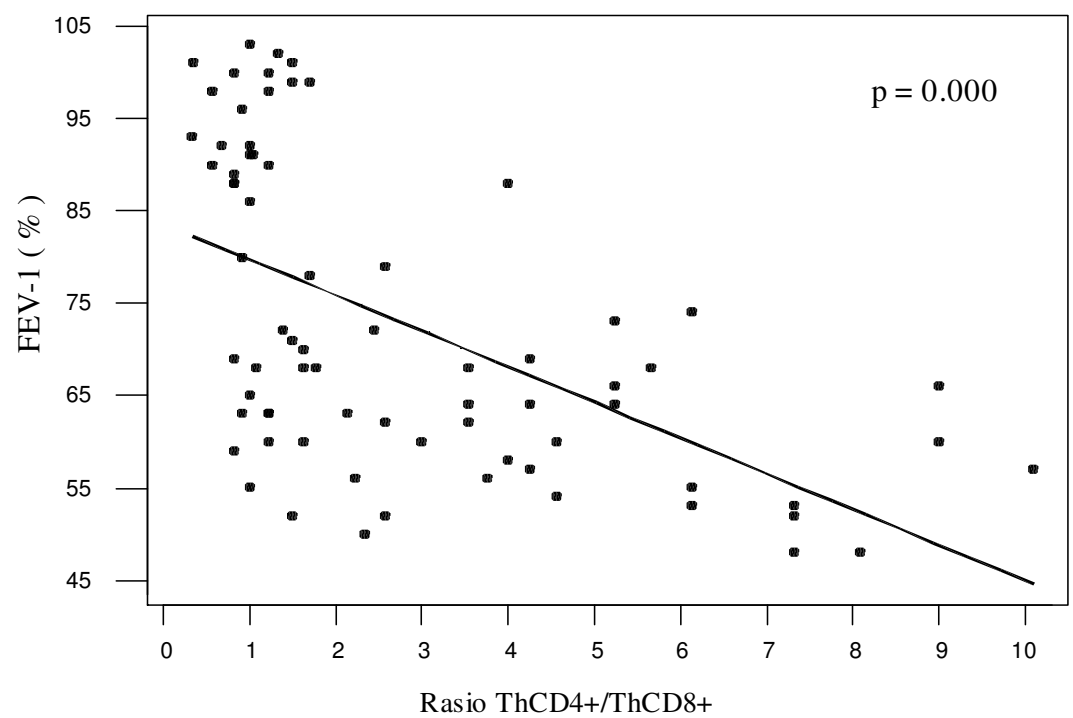

Gambar 4. Hubungan antara derajat asma dengan rasio ThCD4+/TcCD8+ (Regression Plot)

\section{DISKUSI}

Distribusi jenis kelamin pada kasus asma dalam penelitian ini, laki-laki : perempuan $=3,6: 1$, sesuai dengan hasil peneliti lain yang membuktikan bahwa anak laki-laki mempunyai resiko lebih besar untuk menjadi asma dibandingkan anak perempuan $(5,6)$.

Mengapa anak laki-laki lebih sering terkena asma daripada anak perempuan, mekanisme secara pasti sampai sekarang masih belum di ketahui. Beberapa ahli hanya membuktikan bahwa tes kulit yang positif terhadap alergen inhalan lebih banyak di jumpai pada anak laki-laki, hiperresponsibilitas bronkus lebih banyak di temukan pada anak laki-laki, volume paru yang di ukur dengan mengukur maximal expiratory flows di temukan bahwa pada bayi laki-laki lebih rendah, dan diameter saluran napas pada anak laki-laki sebelum mencapai usia pubertas di buktikan bahwa lebih kecil dari diameter anak perempuan $(7,8,9,10)$.

Dalam penelitian ini terbukti pula bahwa jumlah sel eosinofil darah tepi pada saat serangan mempunyai korelasi positif dengan derajat berat asma. Makin tinggi jumlah sel eosinofil darah tepi makin rendah nilai $\mathrm{FEV}_{1}$. Hal ini berbeda dengan peneliti lain yang menyatakan bahwa kenaikan bermakna jumlah eosinofil pada penderita asma tidak mempunyai korelasi dengan penurunan $\mathrm{FEV}_{1}(11,12)$.

Dalam penelitian ini ditemukan pula bahwa terjadi peningkatan jumlah sel Th $\mathrm{CD}_{4}{ }^{+}$, peningkatan Th $\mathrm{CD}_{4}{ }^{+} / \mathrm{Tc}_{\mathrm{C}} \mathrm{CD}_{8}{ }^{+}$ dan penurunan jumlah sel $\mathrm{Tc} \mathrm{CD}_{8}{ }^{+}$. Kejadian tersebut terbukti berkaitan erat secara bermakna dengan kejadian asma dan derajat obstruksi saluran nafas yang digambarkan dalam nilai FEV ${ }_{1}$. Hal ini membuktikan bahwa sel Th $\mathrm{CD}_{4}{ }^{+}$dan $\mathrm{Tc} \mathrm{CD}_{8}{ }^{+}$ mempunyai peran penting dalam potogenesis asma dan dalam menentukan terjadinya asma berat dan mempunyai hubungan yang erat dengan aktivitas penyakit asma $(13,14)$

Masih menjadi pertanyaan bagaimana menjelaskan adanya hubungan derajat berat serangan akut asma yang merupakan proses mekanik dengan peningkatan dan atau penurunan sel-sel inflamasi yang terlibat didalamnya. Dapatkah kondisi mekanik ditentukan oleh kondisi seluler? Apakah peran sitokin atau kemokin yang diproduksi oleh sel-sel inflamasi tersebut yang menentukan kondisi mekanik pada asma?

Penelitian yang dilakukan oleh peneliti lain membuktikan bahwa aktivasi sel neutrofil pada asma berat merupakan sel yang mempunyai peran utama. Hal ini merupakan akibat dari pembentukan sitokin proinflamasi dan enzim yang dilepaskan oleh sel neutrofil tersebut $(4,15)$.

Penelitian ini juga membuktikan bahwa rendahnya FEV 1 atau beratnya derajat obstruksi pada serangan asma mempunyai korelasi dengan makin rendahnya jumlah sel $\mathrm{Tc} \mathrm{CD}_{8^{+}}$. Tetapi peniliti lain membuktikan bahwa sel $\mathrm{Tc}_{\mathrm{C}} \mathrm{CD}_{8}{ }^{+}$mempunyai peran penting dalam proses kerusakan yang terjadi pada kematian karena asma. Kejadian ini ternyata berhubungan dengan adanya infeksi virus yang mendahului serangan asmanya $(16,17)$.

\section{KESIMPULAN}

Dari penelitian ini dapat disimpulkan bahwa serangan akut asma lebih sering terjadi pada anak laki-laki. Jumlah sel $\mathrm{Th} \mathrm{CD}_{4}{ }^{+}$, Tc $\mathrm{CD}_{8}{ }^{+}$dan eosinofil di darah tepi dapat menggambarkan beratnya derajat serangan asma. Masih perlu dilakukan penelitian peran sitokin dan kemokin dalam menentukan derajat berat serangan akut asma. 


\section{DAFTAR KEPUSTAKAAN}

1. Jatakanon A, Uasuf C, Maziak W, et al. Neutrophilic Inflammation in Severe Persistent Asthma. Am. J. Respir. Crit. Care Med. 1999; 160: 1532-1539.

2. Busse WW, Lemanske RF. Asthma. NEJM 2001; 344: $350-362$

3. Ellias JA, Lee CG, Zheng T, Ma B, Homer RJ, Zhu Z. New Insight Into the Pathogenesis of Asthma. JCI. 111(3): 291.

4. Renauld J-C. New Insights Into the Role of Cytokines in Asthma. J. Clin Pathol 2001; 54: 577-589.

5. Chandrakusuma HMS, Masdar Mu'id, Santosa NB, Sumakto, Mardhany YS. Prevalensi dan Faktor Risiko Asma Pada Murid Sd Se Kodya Malang, Konika X, Bukit Tinggi. 1996.

6. Martinez FD. Risk factors for the development of asthma. In: Naspitz CK, Szefler SJ, Tinkelman DG, Warner JO. Textbook of Pedatirc asthma. An international perspective. London: Martin dumitz Itd; 2001: 67-82.

7. Shaw RA, Crane J, O'Donnell TV. Prevalence of Asthma in Children. BR Med J 1990; 300: 1652-1653.

8. Burrows B, Sears MR, Flannery EM, et al. Relations of Bronchial Responsiveness to Allergy, Skin Test Reactivity, Lung Function, Respiratory Symptoms and Diagnoses in Thirteen - Year - Old New Zealand Children. J Alergy Clin Immunol 1995; 95: $548-556$.

9. Martinez FO, Morgan WJ, Wright AL, et al. Diminished Lung Function as a Predisposing Factor for Wheezing Respiratory IIIness in Infants. N. Engl J.Med. 1988; 319: 1112-1117.

10. Pagtakhan RD, Bjeeland JC, Landau LI, et al. Sex Differences in Growth Patterns of the Airways and Lung Parenchyma in Children. J Appl Physiol 1984; 56: 1204-1210.

11. Tobin MJ. Asthma, Airway Biology, and Nasal Disorders in AJRCCM. 2001. Year in Review. Am J Respir Crit Care Med. 2002; 165: 598-618.

12. Gibson PG, Simpson JL, Hankin R, Powell H, Herry RL. Relationship Between Induced Sputum Eosinophilis and the Clinical Pattern of Children Asthma. Thorax. 2003; 58: 116-121.

13. Barkowiak M, Kolecki P, Alkiewicz J. Activation of T Lymphocyte and Severity of Atopic Bronchial Asthma in Children. Pneumonal Alergol Pol. 1995; 63(9-10): 490-497.

14. Seneviratne SL, Jones L, King AS et al. Allergen Spesific CD8+T Cells and Atopic Disease. J. Clin. Invest 2002; $110: 1283-1291$.

15. Ordonez CL, Shaughnessy TE, Matthay MA, Fahy JV. Increased Neutrophil Numbers and IL-8 Levels in Airway Secretions in Acute Severe Asthma. Am. J. Respir. Crit. Care Med. 2000; 161 (4): 1185-1190.

16. O'Sullivan S, Cormican L, Faul JL, et al. Activated, Cytotoxic CD8+ T Lymphocytes Contribute to the Pathology of Asthma Death. Am. J. Respir. Crit. Care Med. 2001; 164 (4): 560-564.

17. Mc Fadden ER. Acute Severe Asthma. Am. J. Respir. Crit. Care Med. 2003; 168: 740-759. 
